\title{
Multi Performance Optimizationof Shoulder Milling Process Parameters of AA6063 T6 Aluminium Alloy by Taguchi Based GRA
}

\author{
Om Prakash Singh, Gaurav Kumar, Mukesh Kumar
}

\begin{abstract}
In this paper, a grey relational analysis method based on Taguchi is proposed to improve the multi-performance characteristics of VMC shoulder milling process parameters in the processing of AA6063 T6. Taking into account four process parameters such as coolant, depth of cut,speed and feed, there are three level of each process parameter in addition to two levels of coolant. 18 experiments were used by L18 orthogonal array using the taguchi method. Multi-performance features like surface roughness and material removal rate are used. Grey Relational Analysis method is used to obtain the Grey Relational Grade, and the multiperformance characteristics of the process are pointed out. Then, the Taguchi response table method and ANOVA are used to analysis data. In order to ensure the validity of the test results, a confirmation test was conducted. The study also shows that this method can effectively improve the multi-function characteristics of shoulder milling process.In his work microstructure and mechanical properties of AA6063 T6before and after shoulder milling have been investigated.
\end{abstract}

Index Terms: Shoulder Milling, Surface roughness, Material removal rate, Multi-performance, Optimization.

\section{INTRODUCTION}

Surface integrity always plays a key role in machining operations. Now a day's of economic and dynamic market conditions and regular improvements in surface integrity have become a top priority for the industry [1]-[4]. With the introduction of advanced tools and equipment, a large number of technologies are developed in the field of processing, so that the surface quality, high quality of surface with roughness, dimensional accuracy, MRR and so on can be produced [5] - [7].

Milling is a versatile machine that is used as one of the important machining method for the machining ofvarious components in industry such as in mining, construction, rail road cars, various kinds of vehicle etc. Most of the components are constructed from machined AA6063 T6.These components are manufactured by number of machining operations where milling operation is extensively used. The reliability of such components is determined by the surface integrity due to its crucial requirement in service life. The surface integrity can be determined by analyzing its following parameters surface roughness, surface strain, etc. This research paper is designed as following: Section II

Revised Manuscript Received on July 20, 2019.

Om Prakash Singh, Mechanical Engineering, Vidya College of Engineering, Meerut, India. Email: omprakash@ vidya.edu.in

Gaurav Kumar, Mechanical Engineering, Vidya College of Engineering, Meerut, India.

Mukesh Kumar, Mechanical Engineering, Vidya College of Engineering, Meerut, India. represents the literature review of the correlated researches to the several applications, approaches and problems of recognizing the development of machining. Experiments will be described on section III including the experimental setup. Section IV explains the method of analyzing. Section V will represent the result and discussion. At lastSection VI will describe the conclusions and proposing some promising future work.

\section{LITERATURE REVIEW}

Earlier, Sun and Guo [8] conducted an experimental study of $\mathrm{Ti}-6 \mathrm{Al}-4 \mathrm{~V}$ to fully characterize surface integrity under various milling condition. They concluded that the value ofroughness in the direction of feed decreases with cutting speed. V.S.Kathavateand A.S.Adkine [9] carried out on Al 7075 material by creating L9 orthogonal array based on taguchiconcept. In this feed, depth of cut and spindle speed kept as controlled process parameters. S/N ratio has used for the optimization of all responses. M. D. G.Ramya et al. [10] conducted the different experiment to improve surface finishing of 6061 aluminium alloy by Taguchi Parameter Design Approach. The experiment performed on computer numeric control milling machine used by carbide tool, insert cutter and High-Speed Steel cutter considering depth of cut, feed and spindle speed as input parameters and optimized these for better surface finishing. N.L. Bhirudand R.R. Gawande [11] determined the impact of heat generated during the machining of materials of high conductivity. Performed end milling on Al 6063 in absence of coolant. Number of flutes, depth of cut, feed rate and speed were considered as control factors during experimentation. Design of experiments was done on the basis of Taguchi method and L18 orthogonal array was selected. $\mathrm{S} / \mathrm{N}$ ratio was calculated and analysis was done by using the smaller-the-better characteristics and obtained that depth of cut was most significant factor due to which temperature rise of work piece is affected. S.V. Alagarsamy et al. [12] used taguchi L9 orthogonal array andanalysis of variance (ANOVA) by taking input parameters namely cutting depth of cut, feed and speed upto three levels and optimized them for the material removal rate (MRR) and Surface roughness. Satish Kumar et al. [13] conducted the experiment to obtain minimum surface roughness optimized the input parameters (depth of cut, speed and feed) by using taguchi method during the end milling of AA5052 aluminium alloy on Computer Numeric

Published By:

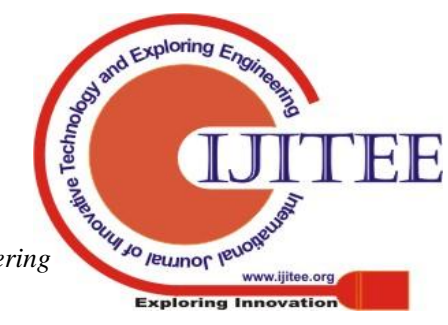


Control end milling machine with the help of High Speed Steel (HSS) End Mill Cutter. V. Jaiganesh et al. [14] conducted nine experiments on mild steel based on Orthogonal Array and generated general linear model for all the three output parameters Material Removal Rate, Chip Thickness Ratio (CTR) and Surface Roughness (SR) by considering Speed, DOC and Time as input parameter. The statistical method called the Analysis of Variance has used to determine critical parameter. The optimum values of Speed, Time, and Depth of Cut were found by using "MINITAB" software. Talwinder Singhet al.[15] used PVD-coated carbide cutting inserts to investigate the effects ofparameters of turning such as Cutting Speed, Feed Rate and Depth of Cut on tool flank wear andquality of machined surface of stainless steel 304 during the turning under nanofluid Minimum Quantity Lubrication condition.

The survey of literature shows that the machining problem of AA6063 T6 like tool worn out, high surface roughness and MRR is extremely high in industries. The problems associated with super finishing of AA6063 T6 by the machining process constitute one of the major reasons for selection of AA6063 T6 as material ofwork piece. The effects of shoulder-surface milling parameters such as coolant, feed, doc and cutting speed on the surface roughness of AA6063 T6 were studied. The shoulder milling condition of the optimum surface quality is determined by using thetools of optimization such as Taguchi technique.

\section{EXPERIMENTS}

\section{A. Material}

Machined AA6063 T6material was used for experimental investigations. General purpose AA6063 T6 is the standard was selected as it is most versatile and most widely used. The samples of AA6063 T6 pieces used during experimentation are as shown in figure1.

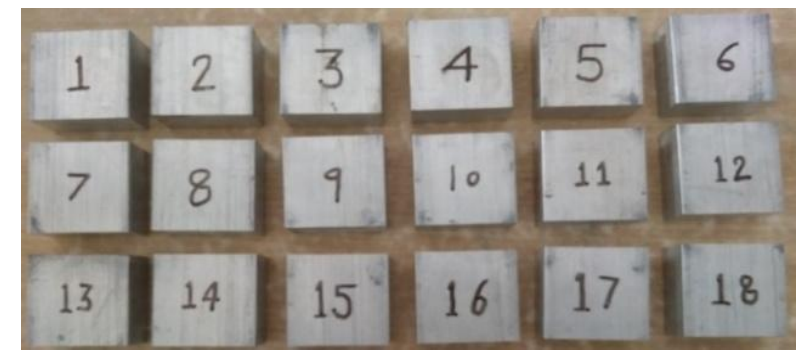

Fig. 1AA6063 T6 Aluminium alloy pieces

The chemical constituents of AA6063 T6work material used for experimental investigation are as shown below in Table I.

Table-I. Chemical Constituents of AA6063 T6 Material

\begin{tabular}{|c|c|c|c|}
\hline Element & $(\% \mathbf{w t})$ & Element & (\% wt) \\
\hline $\mathrm{Al}$ & 98.50 & $\mathrm{Sn}$ & $<0.002$ \\
\hline $\mathrm{Cu}$ & 0.025 & $\mathrm{Ti}$ & 0.022 \\
\hline $\mathrm{Mg}$ & 0.601 & $\mathrm{Cr}$ & 0.006 \\
\hline $\mathrm{Si}$ & 0.490 & $\mathrm{~V}$ & 0.010 \\
\hline $\mathrm{Fe}$ & 0.252 & $\mathrm{~Pb}$ & $<0.001$ \\
\hline $\mathrm{Ni}$ & $<0.008$ & & \\
\hline $\mathrm{Mn}$ & 0.030 & & \\
\hline $\mathrm{Zn}$ & 0.049 & & \\
\hline
\end{tabular}

The VMC milling machine at M/s Crystal Precision Pvt. Ltd, Meerut was used to conduct the shoulder milling operations on the sample pieces.

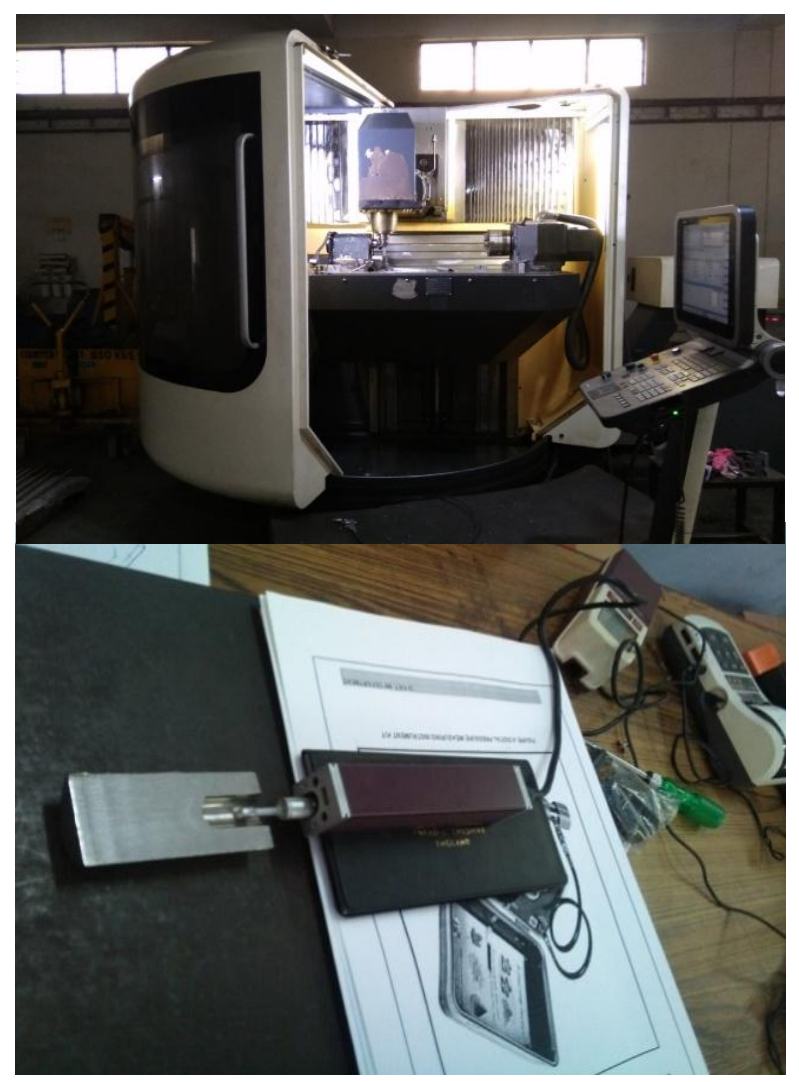

Fig.2 VMC Milling Machine

Fig.3 Surface Roughness Tester

Table-II. Working Conditions

\begin{tabular}{|l|l|}
\hline Condition & Specification \\
\hline Specimen & AA6063 T6 \\
\hline Size of specimen & $50 \mathrm{~mm}$ x $50 \mathrm{~mm}$ x $25 \mathrm{~mm}$ \\
\hline Milling machine & $\begin{array}{l}\text { VMC milling machine (DMU } \\
80 \text { Mono Block) }\end{array}$ \\
\hline Cutter used & $\begin{array}{l}\text { Solid Carbide end mill tool (M - } \\
\text { series) } \varnothing 12\end{array}$ \\
\hline $\begin{array}{l}\text { Measuring } \\
\text { instrument }\end{array}$ & $\begin{array}{l}\text { Mitotoyo surface roughness } \\
\text { tester }\end{array}$ \\
\hline Coolant & Blastocut 4000 (7\% with water) \\
\hline
\end{tabular}

\section{Experimental Design}

Experiments were carried out according to design of experiment like $\mathrm{L}_{18}$ orthogonal array on a VMC milling machine. ANOVA was used to find the optimum combination of machining parameters for those processes having multi-performance characteristics.

Four main shoulder milling parameters like coolant, feed, doc and speed and their levels during machining were determined as given in Table III. 
Table-III. Machining Parameter and Their Levels

\begin{tabular}{|c|c|c|c|c|}
\hline Notation & Parameter & $\mathbf{1}$ & $\mathbf{2}$ & $\mathbf{3}$ \\
\hline A & Coolant & ON & OFF & - \\
\hline B & Feed (mm/min.) & 200 & 350 & 500 \\
\hline C & Doc (mm) & 0.15 & 0.25 & 0.35 \\
\hline D & Speed (r.p.m.) & 4600 & 5800 & 7000 \\
\hline
\end{tabular}

Experiments were conducted by selecting an appropriate orthogonal array of Taguchi's experimental design. According to the different settings of coolant, feed rate, depth of cut and speed, 18 experiments based on orthogonal array $\mathrm{L}_{18}$ are carried out. The surface roughness of all specimens was measured using a roughness tester. According to ASME B-46.1-2002, the sampling length is selected as $5 \mathrm{~mm}$. MRR is calculated using formulas.

$$
\text { MaterialRemovalRate }=\frac{w \times f \times d}{60} \mathrm{~mm}^{3} / \mathrm{sec}
$$

Where: $\mathrm{f}=$ feed in $\mathrm{mm} / \mathrm{min}$; $\mathrm{d}=$ depth of cut $\mathrm{mm}, \mathrm{w}=$ width of block in mm, width of the each specimen is constant i.e. $25 \mathrm{~mm}$.

The measured surface roughness ( $\mathrm{Ra}$ ) and MRR values are shown in TableIV.

\section{TableIVVALUES OFRESPONSE VARIABLES}

\begin{tabular}{|c|c|c|c|c|c|c|}
\hline Experiments & $\mathbf{A}$ & $\mathbf{B}$ & $\mathbf{C}$ & $\mathbf{D}$ & $\mathbf{R a}(\boldsymbol{\mu m})$ & $\mathbf{M R R}\left(\mathbf{m m}^{\mathbf{3}} / \mathbf{s}\right)$ \\
\hline 1 & 1 & 1 & 1 & 1 & 0.27 & 12.50 \\
\hline 2 & 1 & 1 & 2 & 2 & 0.41 & 20.83 \\
\hline 3 & 1 & 1 & 3 & 3 & 2.71 & 29.17 \\
\hline 4 & 1 & 2 & 1 & 1 & 1.91 & 21.88 \\
\hline 5 & 1 & 2 & 2 & 2 & 1.20 & 36.46 \\
\hline 6 & 1 & 2 & 3 & 3 & 1.32 & 51.04 \\
\hline 7 & 1 & 3 & 1 & 2 & 1.88 & 31.25 \\
\hline 8 & 1 & 3 & 2 & 3 & 2.05 & 52.08 \\
\hline 9 & 1 & 3 & 3 & 1 & 2.44 & 72.92 \\
\hline 10 & 2 & 1 & 1 & 3 & 1.11 & 12.50 \\
\hline 11 & 2 & 1 & 2 & 1 & 0.95 & 20.83 \\
\hline 12 & 2 & 1 & 3 & 2 & 1.11 & 29.17 \\
\hline 13 & 2 & 2 & 1 & 2 & 1.51 & 21.88 \\
\hline 14 & 2 & 2 & 2 & 3 & 1.28 & 36.46 \\
\hline 15 & 2 & 2 & 3 & 1 & 1.75 & 51.04 \\
\hline 16 & 2 & 3 & 1 & 3 & 1.69 & 31.25 \\
\hline 17 & 2 & 3 & 2 & 1 & 2.25 & 52.08 \\
\hline 18 & 2 & 3 & 3 & 2 & 1.55 & 72.92 \\
\hline
\end{tabular}

\section{ANALYSIS METHOD}

\section{A. Signal to noise ratio}

The design of the Taguchi technique provides a systematic, easy and effective technique for the optimization. Depending on the feature type, there are three types of Signal to noise ratios, the smaller-the-better, the greater-the-better, and the nominal-the-better. The details of the calculation of the Signal to noise ratio for these three types of characteristics are available in[16].

\section{B. Data pre-processing} comparable series. For this reason, experimental resulthas normalized in the range between 0 and 1 . Normalization can
In this process, the original series is transferred to a

be achieved in three different ways. The details of normalization can be found in [17].

\section{Grey relational coefficient and grey relational grade}

Grey Relational Coefficient is computed to show the relation between ideal and real results of experiments which has normalized. It can be representing as following:

$$
\xi_{\mathrm{i}}(\mathrm{k})=\frac{\Delta_{\min }+\xi \cdot \Delta_{\max }}{\Delta_{0 \mathrm{i}}(\mathrm{k})+\xi \cdot \Delta_{\max }}
$$

Where $\Delta_{0 \mathrm{i}}(\mathrm{k})$ is the deviation sequence of the reference sequence $\mathrm{x}_{0}^{*}(\mathrm{k})$ and the comparability sequence $\mathrm{x}_{\mathrm{i}}^{*}(\mathrm{k})$, named as,

$$
\begin{aligned}
& \Delta_{0 \mathrm{i}}(\mathrm{k})\left\|\mathrm{x}_{0}^{*}(\mathrm{k})-\mathrm{x}_{\mathrm{i}}^{*}(\mathrm{k})\right\| \\
& \Delta_{\max }=\max _{\forall \mathrm{m} \in \mathrm{i} \forall \mathrm{k}}\left\|\mathrm{x}_{0}^{*}(\mathrm{k})-\mathrm{x}_{\mathrm{i}}^{*}(\mathrm{k})\right\| \\
& \Delta_{\min }=\max _{\forall \mathrm{min} \in \mathrm{i}}\left\|\mathrm{x}_{0}^{*}(\mathrm{k})-\mathrm{x}_{\mathrm{i}}^{*}(\mathrm{k})\right\|
\end{aligned}
$$

$\zeta$ is distinguishing or identification coefficient: $\zeta^{\in}[0,1]$. Generally $\zeta=0.5$ is used.

Analysis of mean (ANOM) is used to compute mean value of the multi functions characteristics i.e. the Grey Relational Grade at different levels of machining parameter. Since the Design of Experiment used in this work is orthogonally, it is promising to find out individual effect of all machining parameters at various levels. The Grey Relational Grade is defined as follows

$$
\gamma_{\mathrm{i}}=\frac{1}{\mathrm{n}} \sum_{\mathrm{k}=1}^{\mathrm{n}} \xi_{\mathrm{i}}(\mathrm{k})
$$

However, because the impact of each factor on the system is not exactly the same in practical applications, Eq. (6) can be modified to:

$$
\gamma_{\mathrm{i}}=\frac{1}{\mathrm{n}} \sum_{\mathrm{k}=1}^{\mathrm{n}} \mathrm{w}_{\mathrm{k}} \cdot \xi_{\mathrm{i}}(\mathrm{k}) \sum_{\mathrm{k}=1}^{\mathrm{n}} \mathrm{w}_{\mathrm{k}}
$$

where $\mathrm{w}_{\mathrm{k}}$ represents the normalized weight of factor $\mathrm{k}$. Given the same weight, equations (6) and (7) are equal.

\section{RESULTS AND DISCUSSION}

\section{A. Optimal parameter combination}

The $\mathrm{S} / \mathrm{N}$ ratio, the corresponding grey relational coefficient and grey correlation degree of the experimental data are calculated as shown in Table $\mathrm{V}$, and the optimum combination of the shoulder milling process parameters is determined on the basis of grey relational analysis. Figure 4 is a milling parameter response diagram of each milling parameter at different levels, showing the average of the grey relational grade. The total average of the grey relational level is represented by the dotted line in figure 4 . As we can see from figure $4, A_{1}, B_{3}, C_{3}$, and $D_{1}$ each show the maximum values for the grey relational levels of $\mathrm{A}, \mathrm{B}, \mathrm{C}$, and $\mathrm{D}$ factors,

Published By: 
respectively. So, $A_{1} B_{3} C_{3} D_{1}$ is the best combination of parameters for multi-performance characteristics of shoulder milling processes.

The optimum cutting conditions obtained in this study seem to be quite logical because of the minimum surface roughness and maximum MRR.At a higher level, that is, at level three, the cutting speed and feed speed are used because each tooth has more feed speed, which leads to the largest MRR.

Table-VCalculated Grey Relational Grade and its Orders

\begin{tabular}{|c|c|c|c|c|}
\hline \multirow{2}{*}{$\begin{array}{l}\text { Expt. } \\
\text { No. }\end{array}$} & \multicolumn{2}{|c|}{ Grey relational coefficients } & \multirow{2}{*}{$\begin{array}{c}\text { Grey } \\
\text { relational } \\
\text { grade }\end{array}$} & \multirow[t]{2}{*}{ Orders } \\
\hline & $\begin{array}{c}\text { Surface } \\
\text { Roughness }\end{array}$ & MRR & & \\
\hline 1 & 0.3333 & 0.3333 & 0.3333 & 18 \\
\hline 2 & 0.3791 & 0.4131 & 0.3961 & 17 \\
\hline 3 & 1.0000 & 0.4904 & 0.7452 & 5 \\
\hline 4 & 0.7672 & 0.4228 & 0.5950 & 10 \\
\hline 5 & 0.5860 & 0.5599 & 0.5730 & 12 \\
\hline 6 & 0.6158 & 0.7120 & 0.6639 & 7 \\
\hline 7 & 0.7592 & 0.5100 & 0.6346 & 8 \\
\hline 8 & 0.8051 & 0.7238 & 0.7645 & 4 \\
\hline 9 & 0.9166 & 1.0000 & 0.9583 & 1 \\
\hline 10 & 0.5637 & 0.3333 & 0.4485 & 16 \\
\hline 11 & 0.5238 & 0.4131 & 0.4685 & 15 \\
\hline 12 & 0.5637 & 0.4904 & 0.5270 & 14 \\
\hline 13 & 0.6635 & 0.4228 & 0.5431 & 13 \\
\hline 14 & 0.6059 & 0.5599 & 0.5829 & 11 \\
\hline 15 & 0.7250 & 0.7120 & 0.7185 & 6 \\
\hline 16 & 0.7095 & 0.5100 & 0.6097 & 9 \\
\hline 17 & 0.8611 & 0.7238 & 0.7925 & 3 \\
\hline 18 & 0.6736 & 1.0000 & 0.8368 & 2 \\
\hline
\end{tabular}

From Table VI, the study found that the difference between the maximum and minimum values of the grey relational level of factor $\mathrm{B}$ was the largest, followed by factors C, D and A. Thisshows that the feed rate has a great influence on the multi-performance characteristics.

Table-VIResponse Table for Grey Relational Garde

\begin{tabular}{|l|l|l|l|l|l|}
\hline \multirow{2}{*}{ Symbol } & \multicolumn{5}{|l|}{} \\
\cline { 2 - 6 } & $\begin{array}{l}\text { Drilling } \\
\text { Machining } \\
\text { Parameter }\end{array}$ & $\begin{array}{l}\text { Level } \\
\mathbf{1}\end{array}$ & $\begin{array}{l}\text { Level } \\
\mathbf{2}\end{array}$ & $\begin{array}{l}\text { Level } \\
\mathbf{3}\end{array}$ & $\begin{array}{l}\text { Max - } \\
\text { Min }\end{array}$ \\
\hline A & Coolant & 0.6293 & 0.6142 & & 0.0151 \\
\hline B & Feed Rate & 0.4864 & 0.6127 & 0.7661 & 0.2796 \\
\hline C & Depth of Cut & 0.5274 & 0.5962 & 0.7416 & 0.2142 \\
\hline D & Speed & 0.6443 & 0.5851 & 0.6358 & 0.0592 \\
\hline
\end{tabular}

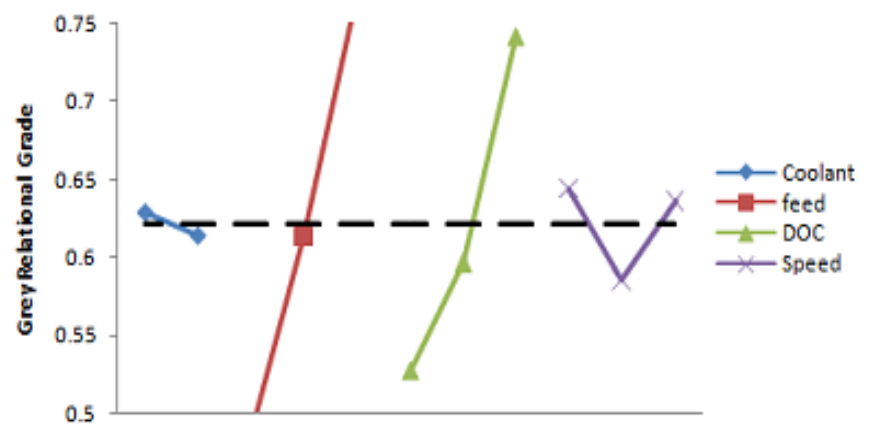

$\begin{array}{lllllllllll}A 1 & A 2 & B 1 & B 2 & B 3 & C 1 & C 2 & C 3 & D 1 & D 2 & D 3\end{array}$

Factors and their levels

Fig.4Effect of milling parameter levels on the multi-performance

\section{B. Analysis of variance}

Studying the analysis of variance of shoulder milling machining parameters can significantly affect the performance characteristics. The execution confidence of analysis of variance is $95 \%$ to evaluate important factors that may affect the required output parameters. Statistically, there are tools called $\mathrm{F}$ tests that can see which parameters have a significant impact on quality characteristics. Typically, when $\mathrm{F}>4$, this means that changes in process parameters have a significant impact on quality characteristics.

TABLEVII RESULT OF ANALYSIS OF VARIANCE

\begin{tabular}{|l|l|l|l|l|l|l|}
\hline $\begin{array}{l}\text { Symb } \\
\text { ol }\end{array}$ & $\begin{array}{l}\text { Machining } \\
\text { parameters }\end{array}$ & Dof & $\begin{array}{l}\text { Sum of } \\
\text { squares }\end{array}$ & $\begin{array}{l}\text { Mean } \\
\text { square }\end{array}$ & $\begin{array}{l}\text { F- } \\
\text { value }\end{array}$ & $\begin{array}{l}\text { Contr } \\
\text { i-buti } \\
\text { on } \\
(\%)\end{array}$ \\
\hline A & Coolant & 1 & 0.0010 & 0.0010 & 0.2029 & 0.23 \\
\hline B & Feed rate & 2 & 0.2353 & 0.1176 & 23.117 & 53.10 \\
\hline C & Doc & 2 & 0.1436 & 0.0718 & 14.106 & 32.40 \\
\hline D & Speed & 2 & 0.0123 & 0.0061 & 1.2085 & 2.78 \\
\hline Error & & 10 & 0.0509 & 0.0051 & & 11.49 \\
\hline Total & & 17 & 0.4431 & & & 100.0 \\
\hline
\end{tabular}

Table VII shows that out of the four machining parameters, three machining parameters such as feed rate andspeedhave a significant effect on the multi-performance characteristics of the shoulder milling process. The coolant and depth of cut range given in Table VII has little effect on the multi-performance characteristics because the $F$ value of the shoulder milling is less than 4 .

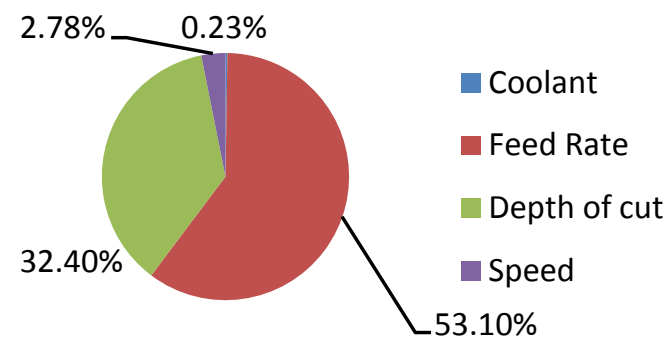

Fig.5. Percentage Contribution of machining parameters 
The results of analysis of variance also show that the feed rate $(53.10 \%)$ is the most significant shoulder milling process parameters, followed by depth of cut $(32.40 \%)$, speed $(2.78 \%)$ and coolant $(0.23 \%)$ as shown in figure 5 .

\section{Confirmation test}

The optimum parameter conditions were determined by Taguchi method, and the verification experiment was carried out in Table VIII. The results show that the experimental results of surface roughness and material removal rate are in good agreement with the prediction of the analysis model.

Table-VIII Results of Confirmation Test

\begin{tabular}{|l|c|c|c|}
\hline \multicolumn{4}{|c|}{ Optimal Machining Parameter } \\
\hline & Prediction & Experiment & \% Change \\
\hline Level & $\mathrm{A}_{1} \mathrm{~B}_{3} \mathrm{C}_{3} \mathrm{D}_{1}$ & $\mathrm{~A}_{1} \mathrm{~B}_{3} \mathrm{C}_{3} \mathrm{D}_{1}$ & \\
\hline $\begin{array}{l}\text { Surface } \\
\text { roughness }\end{array}$ & & 0.9166 & \\
\hline MRR & 0.9161 & 0.9583 & 4.60 \\
\hline $\begin{array}{l}\text { Grey } \\
\text { relational } \\
\text { grade }\end{array}$ & & 1.0000 & \\
\hline
\end{tabular}

The grey relational grade increased from 0.9161 to 0.9583 that is, increased by 4.60 .

\section{Optical Micrographs}

Microscopic examination of ninth specimen was done because it is most reliable and important way to evaluate surface integrity by using identification of micro cracks, micro defects, micro structural changes etc. Mostly surface defects like flaws or micro cracks depend on the condition of machining. It is, consequently, necessary to use special metallographic technique and instrument like Optical microscopy to inspect the surface characteristics. Only surface roughness does not replicate the behaviour of specimen surfaces. The fundamental study was done to examine possibilities of the micro structure and surface treatment on aluminium alloy (AA 6063 T6) substrates. In addition to these variables, microstructure study was also carried out where maximum surface strain was observed. The microstructure photograph was taken by Optical microscopy (Make RsametUnitrom), having $200 \mathrm{X}$ capacities and are shown in Figures 6(a)-6(b) respectively. The microstructure photograph (Before shoulder milling) in figure 6 (a) shows that structure consists equiaxed grains of $\mathrm{Al}-\mathrm{Mg}_{2} \mathrm{Si}$ eutectic and particles of $\mathrm{Mg}_{2} \mathrm{Si}$ in matrix of aluminium solid solution. This photograph shows some rough surfaces of coarse grain size.

The microstructure photograph (After shoulder milling) in figure 6 (b) shows that structure consists equiaxed grains of $\mathrm{Al}-\mathrm{Mg}_{2} \mathrm{Si}$ eutectic and particles of $\mathrm{Mg}_{2} \mathrm{Si}$ in matrix of aluminium solid solution. This photograph shows some fine grain size.

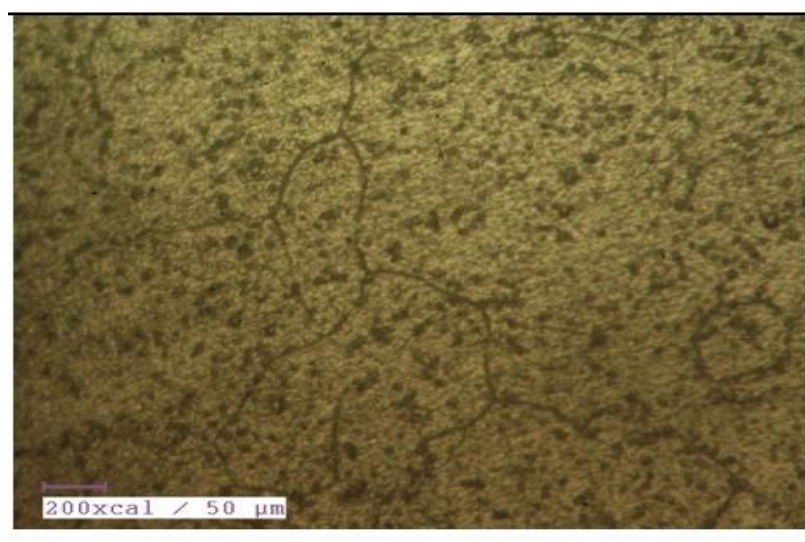

Magnification $200 x$

Fig. 6(a) Microstructure photograph (Before shouldermilling)

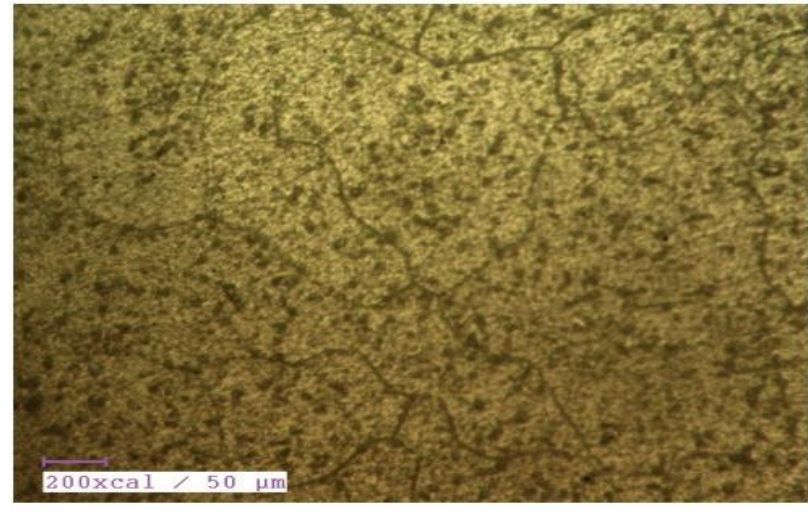

Magnification

$200 x$

Fig. 6(b) Microstructure photograph (Aftershoulder milling)

\section{CONCLUSION}

The best combination of multi-performance characteristics of shoulder milling process is $\mathrm{A}_{1} \mathrm{~B}_{3} \mathrm{C}_{3} \mathrm{D}_{1}$, that is, with coolant, feed rate $500 \mathrm{~mm} / \mathrm{min}$., depth of cut $0.35 \mathrm{~mm}$ and speed4600 rpm. The variance analysis shows that the contribution percentages of feed rate, depth of cut, speed and coolant are 53.10, 32.40, 2.78 and $0.23 \%$, respectively. Using this method, the multi-performance feature improvement of 4.60 is realized. In future other optimization techniques like genetic algorithms can be used for analysis.

\section{ACKNOWLEDGMENT}

The authors are thankful to Vidya Knowledge Park, Meerut for the support, motivation and facilities provided to do this research. 


\section{REFERENCES}

1. Munoz-Escalona, P. and Maropoulos, P.G., "A geometrical model for surface roughness prediction when face milling Al 7075-T7351 with square insert tools", Journal of Manufacturing Systems, Vol.36, pp.216-223, 2015.

2. Azuddin, M. and Abdullah, W, "A Study on surface roughness and burr formation of Al6061 with different spindle speed and federate for small end milling cutter", International Journal of Integrated Engineering,Vol.1,Issue.1, 2009

3. Satish Kumar, P.,Padmanaban, G.,Lingadurai, K., Raja, K. and,Dharmalingam, S., "Investigation on Electrochemical Micro Machining of $\mathrm{Al} 6061-6 \%$ wt $\mathrm{Gr}$ based on Taguchi design of experiments", International Journal of Chem Tech Research, Vol.7,Issue.1, pp.203-211, 2015.

4. Atul, S.C., "Investigation on Chromizing of C45 Steel using Response Surface Methodology", International Journal of ChemTech Research, Vol.9, Issue-1, pp.82-91, 2016.

5. Rawangwong, S.,Boonchouytan, W.,Burapa, R. andChatthong, J., "An investigation of optimum cutting conditions in face milling aluminum 7075-T6 using design of experiment", Lecture Notes in Management Science, Vol. 4, pp.125-135, 2012.

6. Rawangwong, S., Boonchouytan, W., Chatthong, J. andBurapa, R., "An investigation of optimum cutting conditions in face milling semi-solid AA 7075 using carbide tool", International Journal of Innovation, Management and Technology, Vol. 3, Issue 6, pp. 692,2012.

7. Sequeira, A.A., Bhat, T., Sriram, N.S. and Prabhu, R., "Effect of Cutting Parameters on Cutting Force and Surface Roughness of Aluminium Components using Face Milling Process-a Taguchi Approach", IOSR Journal of Mechanical and Civil Engineering, Vol. 3, Issue 4, pp.7-13,2012.

8. Sun, J. and Guo, Y.B., "A comprehensive experimental study on surface integrity by end milling Ti-6Al-4V", Journal of Materials Processing Technology, Vol. 209, Issue 8, pp. 4036-4042, 2009.

9. Kathavate, V.S. and Adkine, A.S., "Multiobjective Optimization in Micromachining of Aluminum (Al 7075) using Taguchi Technique". European Journal of Engineering Research and Science, Vol. 1,Issue 3, pp.25-30, 2016.

10. Ramya, G., Gopikrishna, N., and Kumar, B.S, "Optimization of Milling Process Parameters using Taguchi Parameter Design Approach", International Journal of Nanotechnology and Applications, Vol. 11, Issue 4, pp.293-304, 2017.

11. Bhirud, N.L. and Gawande, R.R., "Optimization of process parameters during end milling and prediction of work piece temperature rise" Archive of Mechanical Engineering, Vol. 64, Issue 3, pp.327-346, 2017.

12. Alagarsamy, S.V., Raveendran, P., Karthikeyan, K., Saravanan, H., and Ravichandran, M.,"Selection of end Milling Parameters on AA7075-15 Wt.\% B4C Metal Matrix Composites"International Journal of Techno Chem Research, Vol.4, Issue 2, pp.117-124, 2018.

13. Satish Kumar, M.D., M. Venkat Narayana „Jiten Prasad,D., Abhishek Krishna, A. Saravanakumar. and M. Anusha "Parametric optimization of aluminium alloy milling using Taguchi method for surface roughness". International Journal of Scientific Research and Review, Vol.7, Issue 3, pp.516-522,2018.

14. Jaiganesh, V., Sevvel, P. andYokesh Kumar, B., "Optimization of process parameters on commercial mild steel using Taguchi technique", International Journal of Engineering \&Technology, Vol.7, Issue 11, pp.138-142, 2018.

15. Singh, T., Dureja, J.S., Bhatti, M.S.and Dogra, M.,"Multi-response optimization in environment friendly turning of AISI 304 austenitic stainless steel", Multidiscipline Modeling in Materials and Structures, Vol. 15,Issue 3,pp.538-558, 2019.

16. Siddiquee, A.N., Mallick, Z.and Khan, Z.A., "Grey relational analysis coupled with principal component analysis for optimization design of the process parameters in in-feed centre less cylindrical grinding”, The International Journal of Advanced Manufacturing Technology, Vol. 46, Issue 9-12, pp.983-992, 2010.

17. Khan, Z.A., Siddiquee, A.N. andKamaruddin, S., "Feasibility study of use of Recycled HighDensity Polyethylene and multi response Optimization of Injection Moulding Parameters using Combined Grey Relational and Principal Component Analysis", Materials \& Design, Vol. 31, Issue 6, pp.2925-2931, 2010.

\section{AUTHORS PROFILE}

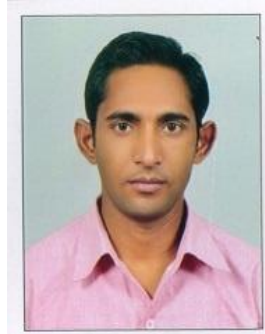

Om Prakash Singhisworking as Assistant Professor in the Department of Mechanical Engineering, Uttar Pradesh Technical University, Lucknow, India.He received his B.Tech degree in Mechanical Engineering in the year 2012. He is currently M.Tech student ofVidya College of Engineering, Meerut, India. His current research interests include High speed machining of non-ferrous alloys.

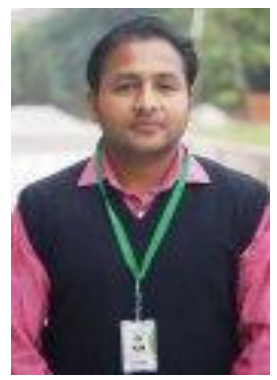

Gaurav Kumarworking as Assistant Professor in the Department of Mechanical Engineering, Uttar Pradesh Technical University, Lucknow, India. He received his B.Tech degree in Mechanical Engineering in the year 2006 and M.E. degree in Manufacturing Technology in the year 2014. Later, he is pursuing his Ph.D. degree in Mechanical Engineering from MM Deemed to be University, India in the year 2015. He has published over 03 papers in different journals and conferences. His areas of research interests includeproduction and industrial engineering.

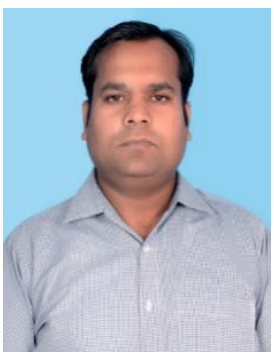

Mukesh Kumarworking as Assistant Professor in the Department of Mechanical Engineering, Uttar Pradesh Technical University, Lucknow, India. He received his B.Tech degree in Mechanical Engineering in the year 2008 and M.Tech. degree in Mechanical Engineering in the year 2015. He has published 03 papers in different journals and conferences. His areas of research interests include production and industrial engineering. 